\title{
The Impact of COVID-19 on the Development of the Segment of the International Tourism Market in Ukraine Focused on Arab Tourists
}

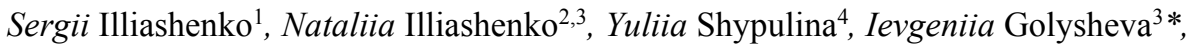 \\ Natalia Tomczewska-Popowycz ${ }^{5}$, Matgorzata Rutkowska ${ }^{6}$, and Janusz Klisinski ${ }^{7}$ \\ ${ }^{1}$ University of Economics and Humanities, Department of Marketing, 43-300, ul. gen. Wł. \\ Sikorskiego 4-4c, Bielsko-Biala, Poland \\ ${ }^{2}$ Sumy State Pedagogical University named after A. S. Makarenka, Department of Business \\ Economics and Administration, 40002, Romenska str., 87, Sumy, Ukraine \\ ${ }^{3}$ Sumy National Agricultural University, Research Section, 40021, Herasyma Kondratieva str., 160, \\ Sumy, Ukraine \\ ${ }^{4}$ National Technical University "Kharkiv Polytechnic Institute", Department of Economic \\ Cybernetics and Marketing Management, 61002, Kyrpychova str., 2, Kharkiv, Ukraine \\ ${ }^{5}$ University of Silesia in Katowice, Institute of Socio-Economic Geography and Spatial Management, \\ 41200, Bedzinska str. 60, Sosnowiec, Poland \\ ${ }^{6}$ Wroclaw University of Science and Technology, Department of Organization and Management, \\ 50370, Wybrzeże Wyspiańskiego str. 27, Wroclaw, Poland \\ ${ }^{7}$ Technical-Humanistic Academy, Department of Marketing and Entrepreneurship, 43309, Willowa \\ str. 2, Bielsko-Biala, Poland
}

\begin{abstract}
The article is devoted to determining the set of external and internal prerequisites for the extending influx of Arab countries' tourists to Ukraine in 2021 under the COVID-19 pandemic restrictions introduced in most countries. Quantitative characteristics of the flow of tourists are outlined. The main characteristics and preferences of tourists from Arab countries who visited Ukraine are determined. It is established that in conditions of restrictions caused by COVID-19, they consider Ukraine as an alternative vocation location to traditional places in European countries. A generalized profile of these tourists has been compiled. It can serve as an information base for improving tourist products (services) and the system of service rendering. An assessment of prospects for developing the international tourism market segment in Ukraine focused on tourists from Arab countries has been made. The study results can be used to make effective management decisions in the field of international tourism at the state and regional levels, as well as at the level of individual tourism service providers in the context of the continuation of the COVID-19 pandemic and its completion. Keywords: international tourism, COVID-19 pandemic, Ukrainian tourist market, development prospects, Arab tourists.
\end{abstract}

\section{Introduction}

\footnotetext{
*Corresponding author: golysheva@gmail.com
} 
The COVID-19 pandemic has negatively affected the entire world economy, especially the tourism industry. Over a hundred countries have imposed various travel restrictions. As a result, revenues from the tourism industry have decreased significantly. According to [1], the average share of tourism in the economy of foreign countries is about $10 \%$, and it suffered significant losses. At the same time, the share of foreign tourists is up to $90 \%$ of the total industry in countries with a developed tourism sphere. Ukraine's tourism industry is less dependent on foreign tourists, accounting for about one-third of the total. However, the situation in Ukraine is somewhat paradoxical - the COVID-19 restrictions, introduced in most countries of the world, facilitated the influx of foreign tourists to Ukraine in 2021, primarily from Arab countries. According to the preliminary analysis results, tourists from Arab countries, who previously gave preferences to other European countries, began visiting Ukraine. These are tourists from Saudi Arabia, the United Arab Emirates, Kuwait, and other countries. According to tour operators' information, the majority of tourists are wealthy people making family vacation trips. This will significantly increase the income of the tourism industry. According to the "Join UP!" travel agency [2, 3], the tourism industry of Ukraine will make an additional UAH 1 billion from tourists from Saudi Arabia and Kuwait in 2021. Consequently, it is necessary to assess the prospects of consolidating the consumer preferences of existing groups of Arab tourists and encouraging their influx to Ukraine. This will purposefully form a system of activity to stimulate the development of the international tourism market in Ukraine both during the COVID-19 pandemic and after its overcoming.

\section{International tourism in a COVID-19 pandemic: literature review}

The impact of the COVID-19 pandemic on tourism has been studied in Abbas et al. [4]. Its authors note significant losses from the pandemic and state the need to restore tourism and traveling activity. In this context, an analysis of methods to restore the tourism industry has been produced. Recommendations on the development and implementation of activities to restore the tourism sector are offered to tourist organizations, public authorities, scientists, etc.

Uğur, Akbıyık [5] investigated the reaction of travelers to the COVID-19 pandemic using text mining methods in online travel forums. The results of in-depth analysis of the texts revealed the impact of travel insurance on decision-making by travelers. The authors consider travel insurance as a method of reviving the tourism industry during a pandemic. It shows the negative impact of the pandemic on tourists themselves and the tourism industry as a whole.

In Saha et al. [6], the impact of the COVID-19 pandemic on the tourism sector of regions and countries was studied. On this basis, a countries ranking was built, which considers the impact of tourism on their economies. The impact of the COVID-19 pandemic on tourism and the world economy has been assessed.

Aronica et al. [7] performed a forecast of the future scenario of the tourism industry based on retrospective data. It provides a steady reduction in foreign tourists, with the most significant reductions expected in developing countries. The main macro-factors that will affect the consequences of the COVID-19 pandemic in different countries are outlined.

Neumayer et al. [8] analyzed a sample of bilateral travel restrictions between 27 European countries for six months during the second wave of the pandemic. Based on the received data, three forecasts made according to epidemiological, economic, and political logic are checked. The results of the analysis show that economic and political logic strongly influences travel restriction. This confirms the need for European countries to pursue a coherent policy of restrictions.

Gegung [9] analyzes the possibility of using virtual travel to traditional tourist locations during the COVID-19 pandemic and after it to maintain sustainable attendance. It also 
contributes to the ecological, cultural, and economically sustainable development of tourist locations and reduces the risk of disease.

Cretu et al. [10] investigated the tourists' attitude to traveling during the COVID-19 pandemic. The study was conducted using the online survey of the active population of Romania. The survey period coincided with the third wave of the pandemic. The results showed that fear of infection and risk significantly affected the intention to travel. These intentions depend on the state of morbidity and protection conditions in the places of travel. However, the very intentions to travel for vacation or leisure have survived.

Kitamura et al. [11] assessed changes in the tourism industry, carbon emissions, and employment in Japan due to the COVID-19 pandemic. They identified and analyzed four scenarios of these changes, and their assessment was performed. Recommendations for overcoming negative economic and social changes and maintaining positive environmental changes in the post-pandemic period were developed.

Tsai [12] is exploring effective strategies for developing Taiwan's tourism industry, which focuses on the most promising consumers of tourism services. The main focus is on analyzing statistics characterizing tourists from China, Japan, and Southeast Asia visits to Taiwan. Treatment and/or vocation tourist directions are analyzed. Recommendations for the formation of strategies for sustainable development of tourism have been developed.

Binh Do et al. [13] investigated the impact of the COVID-19 pandemic on Vietnamese tour operators and analyzed their activity to overcome the predicament. The research is based on the results of a survey initiated by the National Tourism Advisory Council and in-depth interviews with 32 heads of Vietnamese travel companies. Studies have shown a sharp deterioration of the tour operators' business. At the same time, they implement short-term and medium-term anti-crisis activities and practically do not contemplate long-term strategies. The paper emphasizes implementing long-term strategies for the tourism industry to emerge from the crisis caused by the pandemic.

Rahman et al. [14] analyzed the impact of the COVID-19 pandemic on the travel risks of tourists and their perception by tourism business leaders. The initial data were collected through social networks; the sample includes 716 respondents. The obtained results are intended to increase the validity of tourism travel risk management caused by COVID-19.

Hamid et al. [15] conducted a study of the impact of COVID-19 on the tourism industry and hotel services worldwide and in detail (including impact on economic contractors in the field of tourism) in Malaysia. The issue of social integration due to the pandemically accelerated introduction of new creative forms of tourism, which are focused on market niches, was studied. It was concluded that, unlike previous crises, a rapid economic and tourism recovery after the COVID-19 crisis is doubtful. Prokopenko, Omelyanenko [16], on the example of the Baltic region, studied issues of internationalization of clusters of cultural and creative industry, including tourism.

Cheng, Zetina [17] investigated the effects of COVID-19 on the tourism sector in Belize. They showed that the pandemic caused a crisis in the tourism sector and the country's economy as a whole, and it takes time and significant funds to overcome it. Recommendations for overcoming the global crisis in the field of tourism caused by the COVID-19 pandemic were offered.

Pashkus et al. [18] studied the impact of the COVID-19 pandemic on the tourist competitiveness of St. Petersburg (Russia). An approach to determining the competitive advantages of attractive areas for tourism in the post-pandemic period was proposed.

Tomczewska - Popowycz, Quirini - Popławski [19] studied the impact of political instability in Ukraine in the last five years on tourist flows to large cities, identified short and long-term opportunities and threats to tourism development. They found that the impact of political instability on reducing tourist flows was most significant in the regions neighboring the aggressor country. These regions and cities were the objects of tourism for the inhabitants 
of the aggressor country. Their flow reduced sharply. However, tourism development continues in distant conflict regions and cities with a developed tourist background.

Iastremska, Kononova [20] investigated the short-term impact of the COVID-19 pandemic in 2019-2020 on international tourism worldwide, including separate regions of the world in particular. The main tendencies of change of directions and quantitative parameters of tourist flows at different pandemic stages are revealed. Activities to restore the tourism industry are proposed, forecasts of recovery dates are made. The main features and problems of the tourist sphere of Ukraine are revealed.

Summarizing the analysis results, we should note an in-depth study of the impact assessment of the COVID-19 pandemic on international tourism, forecasting scenarios for its future development, recommendations for overcoming the crisis, and recovery. However, the issues related to the analysis of the paradoxical increase in the influx of international tourists, mainly tourists from Arab countries to Ukraine during the COVID-19 pandemic, remained virtually unexplored. Their definition will allow us to assess the prospects for the restoration of international tourism in Ukraine and other countries in the future and purposefully manage these processes.

\section{Purpose, aims, and research methods}

The study aims to determine preconditions for increasing the tourists' influx from Arab countries to Ukraine in conditions of the COVID-19 pandemic, clarify their main preferences, and assess the prospects of formation and development of the international tourism market segment in Ukraine.

Consequently, the following research objectives were identified:

1) to determine preconditions for increasing the Arab tourists' influx to Ukraine during the COVID-19 pandemic, as well as the quantitative characteristics of the flow;

2) to determine the main characteristics and preferences of tourists from Arab countries visiting Ukraine;

3) to determine the prospects of formation and development of the international tourism market segment in Ukraine, which is focused on tourists from Arab countries during the pandemic COVID-19 and after its completion.

Backgrounds for the increasing tourists' inflow from Arab countries to Ukraine in 2021 and its quantitative characteristics were determined based on the analysis of latest information characterizing economic, social, environmental problems of the state and tourism regions, including analytical data of public authorities; data from specialized analytical agencies; open data of travel agencies, as well as tourist infrastructure facilities; media publications, etc. According to the analysis results using the synthesis method, the profiles of typical consumers of tourist services - residents of Arab countries who visited Ukraine were also compiled. The SWOT-analysis method was used to assess the prospects for developing the international tourism market segment in Ukraine focused on tourists from Arab countries.

\section{Results of the study of the COVID-19 pandemic impact on the development of the international tourism market segment oriented to Arab tourists in Ukraine}

\subsection{Backgrounds for the increasing Arab tourists' inflow to Ukraine during the COVID-19 pandemic}

According to travel agencies, the sharp increase in the flow of Arab tourists to Ukraine started with the Decree of the President of Ukraine of July 21, 2020, on establishing a visa-free 
regime for citizens of several Arab countries [21]. In January 2021, an agreement on air services between Ukraine and Saudi Arabia was signed. Currently, the number of flights is several dozen per week. The first flights took place to Kyiv. In July 2021, the Ukrainian "SkyUp" airline began charter flights from Saudi Arabia to Lviv and direct flights to Odesa. Flights to Kuwait (Jazeera Airways) were established, flights to Qatar were resumed.

A significant role played in Saudi Arabia in May 2021 repealing the ban on departure of its vaccinated citizens and those who had contracted the disease. At the same time (in May 2021), the 'Visit Ukraine' presentation (association of representatives of the tourist transformation of Ukraine) [22] with a group of Ukrainian tour operators took place at the Arabian Travel Market international exhibition in Dubai. Thus, tourists accustomed to travelling in Europe were presented with a new route. It was presented as an alternative to closed France, Switzerland, Spain, and other traditional Saudi Arabia tourists' vocation. Activities of state support to promote tourism in Ukraine for Arab countries' residents should also be mentioned.

An example is the meeting held on July 29, 2021, between the Minister of Culture and Information Policy of Ukraine and heads of diplomatic missions of Qatar, Kuwait, and Saudi Arabia in Ukraine. Its main topic was the expansion of cooperation in the field of tourism and culture [23]. Well-known bloggers from Saudi Arabia, who visited Ukraine and shared their positive impressions, also contributed to popularizing tourism in Ukraine [2].

Ukraine is an accessible and attractive country primarily for family vacations of Arab tourists. This is facilitated by:

- moderate and mild climate, which allows you to relax from the heat that is typical for this time of year in Arab countries, especially the Gulf countries;

- picturesque nature (forests, rivers, lakes), not typical for hot climate;

- large cities that tourists are accustomed to visiting in Western Europe, with exciting architecture, numerous parks, and attractions;

- interesting excursion programs and visits to natural, historical, ethnographic objects;

- significant potential for shopping, in particular, goods with a unique national flavour;

- affordable prices;

- delicious food, suitable for Muslim ethnic groups;

- friendly attitude of the population in general and the tourist infrastructure staff in particular.

These incentives, according to [24], caused an increase in the number of tourists from Saudi Arabia, UAE, Kuwait, Oman, Qatar, and Bahrain more than eight times in three months of 2021 (up to 35 thousand people) compared to 2019 (pre-crisis year). Moreover, in the first half of 2021, compared to the second half of 2020, the number of tourists from Saudi Arabia increased 40 times [25]. Tourists from Saudi Arabia, UAE, Oman are leaders of Ukraine among citizens of Arab countries (more than $85 \%$ of the total number of tourists). At the same time, one vacationer from the Persian Gulf countries, according to 'Visit Ukraine' [22, 24], spends an average of USD 2.5 thousand a week.

It should be noted that this is only a tiny proportion of Arab tourists who visited Europe in the pre-crisis period. According to the World Bank [26], in the pre-crisis years, the number of visits to Europe by tourists from only Saudi Arabia, respectively, was: 2015 - 21834000 ; 2016 - 20887000; 2017 - 18607000; 2018 - 17570000; 2019 - 20292000. That means that the tourist potential of the "Arab" segment of the international tourism market in Ukraine is very significant. Of course, not all Arab tourists will prefer Ukraine after repealing restrictions of European countries where they are used to rest. However, a certain proportion of them, especially those who have visited Ukraine, may remain loyal and influence others. In this context, it is essential to identify the prominent locations in which the bulk of tourists are concentrated and establish the reasons for this. This should be further taken into account 
when planning and stimulating the development of the segment of the international tourism market in Ukraine, focused on Arab tourists.

Geographically, most Arab tourists are concentrated in Kyiv, Lviv, and the Carpathians (Bukovel), Odesa. The analysis shows that these locations include almost all the tourists as mentioned above' interests; in addition, there is a large mass of five-star hotels in great demand. From these positions, other regions of Ukraine tendering similar services and conditions are advised to consider in the future. These are Kharkiv and Kharkiv region, Dnipro and Dnipropetrovsk region, Zaporizhia and Zaporizhia region. etc., which have 4-5star hotels and facilities that may be attractive to Arab tourists.

\subsection{Main characteristics and interests of Arab countries tourists who visited Ukraine in 2021}

The generalization of the results of the analysis of information sources, mainly [2, 22, 3, 27 , $28,29,30,31,32]$, etc., made it possible to consolidate the profile of Arab tourists who visited Ukraine in 2021. The leading indicators that are highlighted and taken into account in determining the profile, as well as their characteristics, are given in Table 1.

Table 1. Generalized profile of Arab tourists in Ukraine

\begin{tabular}{|l|l|}
\hline \multicolumn{1}{|c|}{ Indicator } & \multicolumn{1}{c|}{ Characteristics } \\
\hline Type of tourism & $\begin{array}{l}\text { Primarily family vocation: married couples; families involving children } \\
\text { and often grandparents. Groups of friends meet }\end{array}$ \\
\hline Income level & Average and above average \\
\hline Duration of vocation & Mostly 7-14 days \\
\hline $\begin{array}{l}\text { Specific features of } \\
\text { tourists }\end{array}$ & $\begin{array}{l}\text { Religious people, whose behavior is determined by the requirements of } \\
\text { the Muslim religion. In general, not conflicting }\end{array}$ \\
\hline $\begin{array}{l}\text { Experience in the } \\
\text { level of tourist } \\
\text { service }\end{array}$ & $\begin{array}{l}\text { The vast majority have previously visited European countries and are well } \\
\text { versed in the quality of tourist and related services }\end{array}$ \\
\hline $\begin{array}{l}\text { Accommodation } \\
\text { requirements }\end{array}$ & Mostly five- and four-star hotels \\
\hline $\begin{array}{l}\text { Language of } \\
\text { communication }\end{array}$ & Most speak English, but Arabic is also required. \\
\hline $\begin{array}{l}\text { Requirements for the } \\
\text { service level }\end{array}$ & $\begin{array}{l}\text { High: for the residence, food, transport, service level, taking into account } \\
\text { the norms of their religion, etc. }\end{array}$ \\
\hline $\begin{array}{l}\text { Specific } \\
\text { requirements for } \\
\text { tourists }\end{array}$ & $\begin{array}{l}\text { Large hotel rooms with several bedrooms; availability of certain types of } \\
\text { equipment in bathrooms; large cars for family travel, etc. }\end{array}$ \\
\hline \multicolumn{2}{|c|}{$\begin{array}{l}\text { Entertainment (parks, attractions); natural landscapes, natural phenomena } \\
\text { (including rain); shopping (interested in products of local flavour); } \\
\text { excursions (monuments of nature, history, architecture, ethnography, } \\
\text { etc.); gastronomic preferences (including local cuisine); travel to the } \\
\text { regions of Ukraine, etc. }\end{array}$} \\
\hline
\end{tabular}

As it follows from Table 1, Arab tourists who used to spend summer vacations in western Europe went to Ukraine in 2021. They are well versed in peculiarities of recreation in Europe, at the level of service and prices. Naturally, they require a similar service in Ukraine. Or a fair price/quality ratio for travel and related services. In general, they perceive the prices of tourist services in Ukraine as low. A detailed analysis of the interests of Arab tourists shows that most of them are attracted by nature, shopping with local flavour, gastronomy. Among the shortcomings, they note a relatively low level of service, lack of inscriptions in Arabic 
and lack of Arabic-speaking staff, problems with food for Muslims (halal), bad roads etc. However, positive impressions from Ukraine prevail. They need to be consolidated so that this year's boom, caused by several favourable factors, is the beginning of long-term trends in the Ukrainian market of international tourist services.

The information listed in Table 1 can be used to develop a set of activities to improve tourism services and their rendering systems, which are focused on Arab countries' consumers. It can also be used in assessing the prospects for attraction of Arab tourists to other regions of Ukraine, mentioned in the previous section (Zaporizhia, Dnipropetrovsk, Kharkiv regions, etc.). In this case, the Table 1 characteristics of the generalized Arab tourists' profile should be compared to characteristics of the components of the tourist potential of promising regions (mentioned above and others), in particular [33]: recreational, resort, historical, ethnographic, climatic, religious, ethnic, etc.

\subsection{Prospects for the development of the international tourism market segment focused on Arab tourists in Ukraine}

Prospects were evaluated by the SWOT-analysis method. Table 2 outlines Ukraine's tourism potential's strengths and weaknesses identified according to the consumer demand of Arab tourists (see Table 1). It should be noted that their definition was made for regions visited in 2021 by the majority of Arab tourists.

Table 2. Strengths and weaknesses of the tourist potential of the regions of Ukraine in the context of interests of Arab countries tourists

\begin{tabular}{|c|c|}
\hline Strengths & Weaknesses \\
\hline Picturesque nature, attractive for tourists & \multirow{3}{*}{$\begin{array}{l}\text { Insufficient promotion of tourist services in } \\
\text { cities and regions with high conditions for } \\
\text { Arab tourists: Dnipro, Zaporizhia, Kharkiv, } \\
\text { etc. }\end{array}$} \\
\hline $\begin{array}{l}\text { Mild climate (coolness and humidity), natural } \\
\text { phenomena that are not typical for Arab countries }\end{array}$ & \\
\hline $\begin{array}{l}\text { Cities with numerous architectural and historic } \\
\text { sites, parks }\end{array}$ & \\
\hline $\begin{array}{l}\text { Four- and five-star hotels with friendly and } \\
\text { communicable staff }\end{array}$ & $\begin{array}{l}\text { The low number of four- and five-star hotels, as } \\
\text { well as suites in existing hotels, taking into } \\
\text { account peculiarities of Arab tourists (see Table } \\
\text { 1) }\end{array}$ \\
\hline Visa-free entry to Ukraine & $\begin{array}{l}\text { The low number of suitable autos for Arab } \\
\text { tourists travelling with large families }\end{array}$ \\
\hline $\begin{array}{l}\text { Direct aircraft connections with Arab countries, as } \\
\text { well as between central tourist regions of Ukraine }\end{array}$ & Poor roads condition \\
\hline Low prices & Attempts at price discrimination (overpricing) \\
\hline The friendly attitude of the population of Ukraine & $\begin{array}{l}\text { Insufficient English and Arabic speaking staff } \\
\text { at hotels, restaurants, tourist facilities. }\end{array}$ \\
\hline $\begin{array}{l}\text { Extensive opportunities for shopping (world } \\
\text { brands, as well as goods with a national flavour) }\end{array}$ & $\begin{array}{l}\text { Lack of Arabic inscriptions in hotels, } \\
\text { restaurants, tourist sites. }\end{array}$ \\
\hline $\begin{array}{l}\text { Delicious food, including Ukrainian national } \\
\text { cuisine, taking into account the peculiarities of } \\
\text { Muslim tourists' demand }\end{array}$ & $\begin{array}{l}\text { Few food establishments with a halal } \\
\text { certificate }\end{array}$ \\
\hline $\begin{array}{l}\text { Many natural, historical, architectural, ethnographic, } \\
\text { etc. objects (excursion or independent visit) }\end{array}$ & \multirow[t]{2}{*}{ Few Arabic speaking guides } \\
\hline Numerous objects for entertainment & \\
\hline
\end{tabular}

As follows from Table 2, Ukraine has significant potential for developing the international tourism market segment focused on Arab tourists. Reducing weaknesses is mostly the incompetence of tourism service providers and business entities involved in this process (economic contractors of tourism service providers). However, the correction of some significant shortcomings is a responsibility of state and regional authorities, in 
particular: roads and highways, regulation of the hotel certification system, the food certification system, and so on.

However, the prospects for international tourism development in Ukraine are primarily determined by external factors. At present, they are favourable, but both short-term and longterm perspectives should be analyzed. Table 3 presents the results of the analysis of external opportunities and threats in the context of developing the international tourism segment in Ukraine focused on Arab countries tourists.

As it follows from Table 3, favourable opportunities are primarily caused by the current state of constituent subsystems of the external macro-environment. The threats are related mainly to possible adverse changes, studied from the standpoint of the analyzed segment of the international tourism market in Ukraine.

Table 3. Opportunities and threats for the development of international tourism in Ukraine focused on Arab countries tourists.

\begin{tabular}{|c|c|}
\hline Opportunities & Threats \\
\hline Visa entry to European countries & \multirow{2}{*}{$\begin{array}{l}\text { Repealing or reduction of COVID restrictions } \\
\text { in Europe }\end{array}$} \\
\hline European COVID-restriction for foreigners. & \\
\hline $\begin{array}{l}\text { Repealing the ban on departure of its vaccinated } \\
\text { citizens and those who had contracted the } \\
\text { disease in Saudi Arabia }\end{array}$ & $\begin{array}{l}\text { Intensifying COVID-restrictions in Ukraine is } \\
\text { possible }\end{array}$ \\
\hline $\begin{array}{l}\text { Positive impressions of Arab tourists who } \\
\text { visited Ukraine in } 2021 \text { combined with the } \\
\text { habit of vacationing in Europe }\end{array}$ & $\begin{array}{l}\text { The threat of political and/or economic crisis in } \\
\text { Ukraine }\end{array}$ \\
\hline
\end{tabular}

Thus, the combination of external and internal factors indicates significant prospects for forming and developing the international tourism market segment in Ukraine focused on Arab countries tourists.

\section{Discussion}

Determining the external and internal backgrounds for the 2021 growth of Arab tourists' influx to Ukraine allowed us to outline the range of competitive advantages that are significant for this group of consumers of tourism services in a COVID-19 pandemic. It is shown that competitive advantages are formed on: Ukraine's government and tour operators' successful use of the situation in the field of international tourist services, concerning Arab tourists, which allowed Ukraine to position itself as an alternative to closed European countries; strong tourist potential in several regions of Ukraine, suitable for Arab tourists and conditions like in European countries - internal prerequisites. These preconditions marked the beginning of the formation and development of a promising segment of the international tourism market in Ukraine, focused on Arab tourists. This is evidenced by the quantitative characteristics of the flows of these groups of tourists. The possibility of extending or forming a segment of the international tourism market to other regions of Ukraine is shown. Thus, the possibility of formation and development of new segments of the international tourist services market in the conditions of the COVID-19 pandemic is substantiated, which is connected with the change of directions of tourist flows.

The characteristics of the generalized profile of Arab tourists who visited Ukraine in 2021 form the information background for developing an activity system aimed at improving tourism and related services and the system of their rendering. They can also be used to assess the prospects of attracting Arab tourists to other regions of Ukraine. Thus, the profile data of tourists from Arab countries provide relevant information for effective management decisions in the tourism sector both at the level of tourism service providers and regional and state authorities. A particular disadvantage is that the primary sources of secondary information that summarize the data of individual providers of tourism and related services 
were used in compiling the profile. However, a specified profile gives a complete picture of tourists' preferences, allows to predict their behaviour in consumption and communication, which provides an opportunity to prepare tourist products, provide appropriate conditions for tourism services, train staff interacting directly with tourists, purposefully form customer loyalty. This will ensure Arab tourists' positive impression from a vocation in Ukraine, increase chances of their re-visits, and share positive impressions among potential consumers of tourist services.

The assessment of the possibilities of formation and development of the international tourism market segment in Ukraine focused on Arab tourists, performed by the SWOTanalysis method, testifies significant prospects. The COVID-19 pandemic provided a chance that was used successfully. According to the SWOT analysis results, Ukraine has a strong tourist potential and favourable external conditions (opportunities) for its implementation. In order to maintain the existing positive trends in the development of the international tourist market segment focused on Arab tourists in Ukraine, it is necessary to reduce and amend shortcomings identified by the analysis, which negatively affect the domestic opportunities of the country's tourism sector. However, it is necessary to anticipate the possible consequences of implementing identified external threats and develop activities to avoid or minimize them.

\section{Conclusions and prospects for further research}

The set of external and internal preconditions is determined and their impact on the 2021 growth of the Arab tourist's flow to Ukraine in conditions of COVID-19 pandemic restrictions introduced in most countries. Quantitative characteristics of this growth are outlined, indicating the beginning of the formation and development of the international tourism market segment in Ukraine, focused on Arab tourists. They also testify to the significant economic prospects of Ukraine's tourism industry. The main characteristics and preferences of tourists from Arab countries who visited Ukraine are determined. A generalized profile of Arab tourists is compiled. It shows that tourists who used to spend vacations in other European countries treat Ukraine as an alternative to traditional summer trips. An assessment of the prospects for formation and development of the international tourism market segment in Ukraine, focused on Arab tourists, in the context of the COVID19 pandemic and after its completion was performed.

The obtained results can be used for management decisions at the state and regional levels of tourism development management and the level of individual tourism service providers.

Further research should be aimed at accumulating and analyzing information for 2022 and subsequent years, which characterize trends of formation and development of the international tourism market, focused on Arab countries tourists. It is also necessary to analyze the impacts on the tourism sector caused by the COVID-19 pandemic. This will clarify existing trends and outline the chances for success in the formation and development of this segment of the international tourism market in the future, including the post-pandemic period.

\section{References}

1. The COVID-19 pandemic and its consequences in the field of tourism in Ukraine. Update to the document "Roadmap for competitive development of tourism in Ukraine". Hotel \& Destination Consulting. (2020) URL: http://www.ntoukraine.org/assets/files/EBRD-COVID19-Report-UKR.pdf. 
2. B. Miroshnychenko, M. Tsymbaliuk. Arab tourists have flooded Ukrainian resorts: what attracts them to Ukraine and how to use it. Ekonomichna Pravda, 21 Jule (2021). URL: https://www.epravda.com.ua/publications/2021/07/22/676156/.

3. Join UP!. Official site. URL: https://joinup.ua/.

4. J. Abbas, R. Mubeen, P.T. Iorember, S. Raza, G. Mamirkulova. Current Research in Behavioral Sciences. 2 (2021). https://doi.org/10.1016/j.crbeha.2021.100033.

5. N.G. Uğur, A. Akbıyık. Tourism Management Perspectives. 36 (2021) https://doi.org/10.1016/j.tmp.2020.100744.

6. J. Saha, S. Haldar, S. Bhattacharya, P. Suman. Tourism in retrospect of COVID-19 on global perspective using analytical hierarchy process. Spatial Information Research. (2021) https://doi.org/10.1007/s41324-021-00407-4.

7. M. Aronica, P. Pizzuto, C. Sciortino. The World Economy. 00. 1-15 (2021) https://doi.org/10.1111/twec.13157.

8. E. Neumayer, T. Plümper, M. Shaikh. The logics of COVID-19 travel restrictions between European countries. Social Science Quarterly. (2021) https://doi.org/10.1111/ssqu.13016.

9. E.M. Gegung. Jurnal Kepariwisataan Indonesia: Jurnal Penelitian Dan Pengembangan Kepariwisataan Indonesia, 15(1), 9-15 (2021) https://doi.org/10.47608/jki.v15i12021.9-15.

10. C.-M. Cretu, A.-G. Turtureanu, C.-G. Sirbu, F. Chitu, E. S. Marinescu, L.-G. Talaghir, D.M. Robu. Sustainability. 13, 8405 (2021) https://doi.org/10.3390/su13158405.

11. Y. Kitamura, S. Karkour, Y. Ichisugi, N. Itsubo. Sustainability, 12 (24), 10302 (2020). https://doi.org/10.3390/su122410302.

12. M-C. Tsai. PLoS ONE. 16(3), e0248319 (2021). https://doi.org/10.1371/journal.pone.0248319.

13. D. Binh, N. Ninh, D. Clare, D.B. Huu, N.H. Thi. Tourism and Hospitality Research, 0(0), 1-13 (2021). https://doi.org/10.1177/1467358421993902.

14. M.K. Rahman, M.A.I. Gazi, M.A. Bhuiyan, M.A. Rahaman. PLoS ONE, 16(9), e0256486 (2021). https://doi.org/10.1371/journal.pone.0256486.

15. R. Hamid, N.H.M. Hashim, S.A.M. Shukur, N.H. Marmaya. International Journal of Academic Research in Business and Social Sciences, 11(16), 27-41 (2021). http://dx.doi.org/10.6007/IJARBSS/v11-i16/11213.

16. O. Prokopenko, V. Omelyanenko. TEM Journal, 9(3), pp. 1068-1075 (2021) http://doi.org/10.18421/TEM93-31.

17. J. Cheng, Z. Zetina. Open Journal of Social Sciences, 9, 326-334 (2021). https://doi.org/10.4236/jss.2021.97023.

18. V. Pashkus, N. Pashkus, A. Asadulaev. SHS Web of Conf., 92, 01041 (2021). https://doi.org/10.1051/shsconf/20219201041.

19. N. Tomczewska-Popowycz, Ł. Sustainability, 13, 4126 (2021). https://doi.org/10.3390/su13084126.

20. O. Iastremska, O. Kononova. Three Seas Economic Journal, 2(2), 54-61 (2021) https://doi.org/10.30525/2661-5150/2021-2-9.

21. Decree of the President of Ukraine №289 / 2020. On the establishment of a visa-free regime for citizens of Australia, New Zealand, the Kingdom of Bahrain, the State of Kuwait, the Sultanate of Oman, the Kingdom of Saudi Arabia (2020). URL: https://www.president.gov.ua/documents/2892020-34449. 
22. Visit Ukraine. Official site (2021). URL: https://ukraine.ua/visit/.

23. ICIP intensifies cooperation with Arab countries in the field of tourism and culture. Official site of the Ministry of Culture and Information Policy of Ukraine (2021). URL: https://mkip.gov.ua/news/5808.html.

24. B. Miroshnychenko. Ukraine received 35,000 tourists from the Persian Gulf in three months. Ekonomichna Pravda, 2021, 17 August (2021). URL: https://www.epravda.com.ua/news/2021/08/17/676959/.

25. State Agency for Tourism Development in Ukraine (2021). URL: https://www.facebook.com/DARTUkraine/photos/a.114995336794002/366976171595 916.

26. The World Bank. International tourism, number of arrivals - Saudi Arabia (2021). URL: https://data.worldbank.org/indicator/ST.INT.ARVL?locations=SA.

27. D. Kurishko, G. Erman. How and why Arab tourists fell in love with Ukraine. BBC News Україна, 2021, 7 August (2021). URL: https://www.bbc.com/ukrainian/features58120247.

28. G. Marushchenko. Arab tourists in Ukraine: is the Ukrainian coast ready for guests from the Persian Gulf. O, More, 2021, September 10 (2021). URL: https://omore.city/articles/164482/arabski-turisti-v-ukraini-tradicii-vidpochinku-nauzberezhzhi.

29. G. Tereshchuk. Lviv became famous in the richest country in the world. But for how long? Radio Svoboda (2021). URL: https://www.radiosvoboda.org/a/karantyn-turyzmsaudivska-araviya/31393411.html.

30. D. Kolomiets. $\$ 40$ million to the state treasury. How the Arabs raised the tourism business of Ukraine. Suspilne novyny, 2021, August 28 (2021). URL:

https://suspilne.media/159200-40-miljoniv-dolariv-u-derzavnu-kaznu-ak-arabi-pidnalituristicnij-biznes-ukraini/.

31. Up to 800 euros per day: tourists from Arab countries in Ukraine spend more Europeans - the media. Focus, 2021, September 18 (2021). URL:

https://focus.ua/uk/ukraine/493081-do-800-evro-v-sutki-turisty-iz-arabskih-stran-vukraine-tratyat-bolshe-evropeycev-smi.

32. Arab tourists in Ukraine: where and how much money do they bring? Infographics. Baker Tilly Ukraine, 2021, September 17 (2021). URL: https://bakertilly.ua/news/id50120.

33. S.M. Illiashenko, Y.S. Shypulina, N.S. Illiashenko. Marketing and digital technologies, 5(2), 14-26 (2021) https://doi.org/10.15276/mdt.5.2.2021.2 